
Nama
: Raymond Lim
E-mail
: s130119036@student.ubaya.ac.id

\title{
Keterkaitan antara Informasi Teknologi terhadap Hubungan antara Strategic Orientation dan Firm Performance
}

Technology Turbulence merupakan perkembangan perubahan informasi teknologi dalam proses produksi yang timbul dan menyebar secara tidak beraturan (Celtekligil \& Adiguzel, 2019). (Zhou, Su, Yang, Tao, \& Sohn, 2021) mendefinsikan strategic orientation sebagai sikap dan tingkat strategi sebuah perusahaan dalam menciptakan dan mengembangkan ide baru yang nantinya menjadi produk dan jasa yang dipasarkan. Strategic Orientation sendiri mencerminkan sikap sebuah perusahaan menjalankan bisnisnya dalam rangka mencapai firm performance yang superior (Gotteland, Shock, \& Sarin, 2020). Entrepreneurial strategic orientation memberikan kontribusi untuk mencapai kinerja yang lebih baik ketika sebuah perusahaan dihadapkan pada lingkungan hostile seperti pada sektor dengan high-technology (Löfsten \& Lindelöf, 2005).

(Pratono, 2016) menjelaskan pengaruh informasi teknologi dalam suatu perusahaan melalui laten variabel, yaitu technological turbulence (TT). Sedangkan strategi direpresentasikan melalui variabel laten yaitu strategic orientation (SO) dan kinerja perusahaan direpresentasikan melalui variabel laten yaitu firm performance. Dalam studinya, (Pratono, 2016) menemukan bahwa technology turbulence memiliki dampak moderate terhadap hubungan antara strategic orientation dan firm performance. Intensitas atau tingkat technological turbulence dalam sebuah perusahaan memberikan dampak yang berbeda terhadap firm performance. Dalam kondisi tingkat technological turbulence yang tinggi, firm performance terdampak secara negatif oleh strategic orientation. Di sisi lain, dalam kondisi tingkat technological turbulence yang rendah strategic orientation memberikan dampak yang positif terhadap firm performance.

\section{References}

Celtekligil, K., \& Adiguzel, Z. (2019). Analysis of the effect of innovation strategy and technological turbulence on competitive capabilities and organizational innovativeness in technology firms. Procedia Computer Science, 158, 772-780. doi:https://doi.org/10.1016/j.procs.2019.09.114 
Gotteland, D., Shock, J., \& Sarin, S. (2020). Strategic orientations, marketing proactivity and firm market performance. Industrial Marketing Management. doi:https://doi.org/10.1016/ j.indmarman.2020.03.012

Löfsten, H., \& Lindelöf, P. (2005). Environmental hostility, strategic orientation and the importance of management accounting - an empirical analysis of new technology-based firms. Technovation, 25(7), 725-738. doi:https://doi.org/10.1016/j.technovation.2004. 01.007

Pratono, A. H. (2016). Strategic orientation and information technological turbulence. Business Process Management Journal, 22(2), 368-382. doi: https://doi.org/10.1108/BPMJ-052015-0066

Zhou, W., Su, D., Yang, J., Tao, D., \& Sohn, D. (2021). When do strategic orientations matter to innovation performance of green-tech ventures? The moderating effects of network positions. Journal of Cleaner Production, 279. doi:https://doi.org/10.1016/j.jclepro. 2020.123743 